James G. Crossley, "Life of Brian or Life of Jesus? Uses of Critical Biblical Scholarship and Non-orthodox Views of Jesus in Monty Python's Life of Brian," Relegere: Studies in Religion and Reception I, no. I (20 I I): 93-I I 4. Non-Commercial No Derivatives 3.o License.

Relegere: Studies in Religion and Reception is an independent, open-access academic journal dedicated to the promotion and dissemination of innovative research in reception history, broadly conceived, within and across religious traditions.

Www.relegere.org

ISSN I I 79-723I 


\section{James G. Crossley}

\section{Life of Brian or Life of Jesus?}

\section{Uses of Critical Biblical Scholarship and Non-orthodox Views of Jesus in Monty Python's Life of Brian}

It is often argued that Monty Python's Life of Brian should not be regarded as blasphemous or offensive, largely because Brian and Jesus are two distinct characters in the film. Many religious opponents have claimed otherwise. This article argues that to some degree these pious opponents have a point: Brian does in some way represent Jesus. What Life of Brian does, through interaction with scholarly literature and ideas, is to attribute to Brian a whole host of mildly subversive and critical views about Jesus and effectively create a critical life of Jesus.

G VER SINCE it opened there have been consistent attempts to downplay Cthe perceived blasphemous or disrespectful elements of Monty Python's Life of Brian (Terry Jones, I979). ${ }^{1}$ The standard defence is that the film is not

For pioneering Brianologist, Philip Davies, who has waited a little too long...

James Crossley is Senior Lecturer of New Testament Studies, Department of Biblical Studies, University of Sheffield.

${ }^{1}$ All quotations from and references to Life of Brian are from Monty Python and Graham Chapman, Monty Python's The Life of Brian (of Nazareth) (1979; London: Methuen, 200 I). 
blasphemous or offensive (or at least it should not be taken that way) partly because Jesus is Jesus and Brian is Brian and the two are distinguished in the film, and partly because the film fires at bad religion and bad interpretation rather than at the founder figure. Eric Idle's comments are typical:

Christ is in the movie twice. His birth's in there in the first place and then He's in the Sermon on the Mount. There's no denial of His existence, it's all about churches, that's what it is ... it's about people interpreting, people speaking for God and people wanting to kill for God. ${ }^{2}$

Even Terry Gilliam's diligent churchgoing mother did not see what all the fuss was about because there was, after all, differentiation between Jesus and Brian right at the beginning in the stable scene. ${ }^{3}$ Similar comments have been made by critical scholars such as Carl Dyke:

Brian is not directly blasphemous. Nor would it have a prayer of mainstream acceptance and effectiveness if it were. It is not a broadside or even a shot across the bows so much as a nudge in the ribs. With respect to Jesus, who makes three brief tangential appearances, the movie is downright orthodox. In each case, the message is not that Jesus is wrong, or even that worshipping Jesus is wrong, but that fallible humans find all sorts of creative ways to get worshipping Jesus wrong ... The Pythons' Jesus is not just behaviourally appropriate: he is divine ... In terms of core Christian beliefs, the movie is reverent and unquestioning ... Overall, by accepting the common sense of Jesus' divinity and ethical authority, The Life of Brian locates itself squarely within the hegemonic network of Christianity. ${ }^{4}$

${ }^{2}$ The Pythons, The Pythons: Autobiography (London: Orion, 2003), 385.

${ }^{3}$ Pythons, Autobiography, 385; Robert Sellers, Always Look on the Bright Side of Life: The Inside Story of HandMade Films (London: John Blake, 2003), 2 I.

${ }^{4}$ Carl Dyke, "Learning from The Life of Brian: Saviors for Seminars," in Screening Scripture: Intertextual Connections between Scripture and Film, ed. George Aichele and Richard G. Walsh (Trinity Press International, 2002), 237-38, 240. See also the brief comments in Richard G. Walsh, Reading the Gospels in the Dark: Portrayals of Jesus in Film (Harrisburg: Trinity Press International, 2003), 29-33, 38-39, and "Three Versions of Judas Jesus," in Those Outside: Noncanonical Readings of the Canonical Gospels (New York: T \& T Clark, 2005), I60 n. II. 
These kinds of arguments are necessary partly because there have been, obviously, allegations of blasphemy and offensiveness aimed at the film. Aside from the infamous attacks from Malcolm Muggeridge and Mervyn Stockwood (then Bishop of Southwark) on the BBC 2 (UK) show Saturday Night, Sunday Morning (BBC, 1979), there was uproar aplenty. In America, the film faced protests outside cinemas in New York, it was not shown in parts of the Bible Belt and one Texas cinema received a bomb threat. In the UK there were also the obligatory protests along with prayers encouraged for the film's downfall, arguments made for the imprisonment of the participants, and banning of the film in Harrogate, Swansea (until I 997), parts of Surrey, East Devon and Cornwall. Channel 4 had to wait until r991 to broadcast it on television, six years after it was originally intended for broadcast. It was also banned in Ireland, Norway and Italy. ${ }^{5}$ Film executives also had serious problems with the film. Bernard Delfont of EMI dropped Life of Brian just as filming was due to start because of the script's perceived blasphemous content and meetings with potential backers in America were unsuccessful because of fears surrounding offence. ${ }^{6}$

Yet, in a slightly perverse sense perhaps, I would like to add to the argument that Life of Brian might indeed be offensive, at least in the sense of offensive to those Christians who may personally find reconstructions of the historical Jesus blasphemous rather than an outright attack on the figure of Jesus. This is because, through Brian, the film stealthily constructs a very different Jesus of history from the Christ of faith. ${ }^{7}$ For clarity's sake I hasten to add that I would not be among those wishing imprisonment for its makers (or most biblical scholars) and I would not advocate that the film (or historical Jesus books) should be banned in parts of Surrey, or anywhere else for that matter. On the contrary, I cannot help but endorse, as well as hopefully bolster, Philip Davies's remarks where he points out that the film "not only reflects a higher level of historical and biblical research than nearly all exemplars of the Hollywood genre which count among its targets, but also engages with a number of basic scholarly, historical and theological issues."

${ }^{5}$ For further details of various controversies see Robert Hewison, Monty Python: The Case Against (New York: Grove, I98 I); Sellers, Bright Side, I4-2 I.

${ }^{6}$ Pythons, Autobiography, 365-68.

${ }^{7}$ For uses of the "Christ of faith" and the "Jesus of history" with reference to Life of Brian see Philip R. Davies, "Life of Brian Research," in Whose Bible Is It Anyway? 2nd ed. (London: T \& T Clark International, 2004), I42-1 55, esp. I 50-5 I. This essay was first published in J. Cheryl Exum and Stephen D. Moore, eds., Biblical Studies/Cultural Studies: The Third Sheffeld Colloquium (Sheffield: Sheffield Academic Press, I998), 400-4I 4.

${ }^{8}$ Davies, "Research," I 42. 
The major way in which Monty Python challenges the traditional Christ of faith is by making what should be an obvious intertwining of the lives of Brian and the Jesus of the gospels. Malcolm Muggeridge and Mervyn Stockwood recognised this when they suggested to John Cleese and Michael Palin that Brian was obviously Christ. That said, Muggeridge and Stockwood had missed the first fifteen minutes of the film where the sort-of-distinction is made. ${ }^{9}$ Yet, pretentious though their evidence-lite posturing infamously was, Muggeridge and Stockwood still have a point: there is significant overlap between the characters. Jesus and Brian are born at the same time and at the same place. The baby Brian is even mistaken for the baby Jesus by the three wise men. The other key distinction scene is where Jesus gives the Sermon on the Mount. Yet even the Mount provides another notable similarity. In the screen version of the film a special cameo character is reserved for the film's eleventh-hour backer, George Harrison. This character is Mr Papadopolous, who happened to reserve the Mount for Brian.

In fact numerous aspects of the lives of Brian and Jesus have explicit similarities. Brian is also named with reference to his hometown (i.e., Brian of Nazareth) which just so happens to have been the case with Jesus (e.g., Matt 2:23). Both Brian and Jesus were, of course, proclaimed "the Messiah" by followers. As people asked Jesus for "a sign" (e.g., Matt I 2:38; I 6: I) which Jesus can refuse to give (e.g., Mark 8: I2; Matt I 2:39; I6:4) so people ask for "a sign" which Brian does everything but give. ${ }^{10}$ Their use of language is often intimately similar and regularly laced with comic twists, at least in the case of Brian. This is particularly so when Brian has to pose as a prophet to avoid detection by the Romans. The following examples are quite straightforward parallels to some of the more famous sayings of Jesus:

Don't pass judgement on other people, or you might get judged yourself. (53; cf. Matt 7:I-2)

Consider the lilies ... Well the birds then.... Have they got jobs?... They [the birds] eat but they don't grow anything, do they?... OK. And you're more important than they are, right? Well there you are then. What are you worrying about. (54; cf. Matt 6:25-34)

${ }^{9}$ Pythons, Autobiography, 384-85; Sellers, Bright Side, I9.

${ }^{10}$ Python and Chapman, Life of Brian, 59-60, 62-64. For a list of the "sign" passages in the gospels see Davies, "Research," I 47. 
Look there was this man and he had two servants.... And he gave them some talents ... there were these two servants ... or wait a moment were there three?... Three ... well stewards actually. (cf. Matt I 8:23-35; 21:28-32; 25:I4-30; Luke I6:I-8; I9: I I-27)

Er hear this! Er ... Blessed are they ... who convert their neighbour's ox ... for they shall inhibit their girth ... and to them only shall be given. (55; cf. Matt 5:I-I2; Luke 6:20-26. See also Exod 20:17; Deut 5:2I.)

The respective deaths of Jesus and Brian are also very similar. Not only are both crucified but both are crucified as revolutionary threats (Mark I 5:6-I6, 27). These blindingly obvious parallels should immediately prick the ears of any critic who wishes to know whether the film is trying to say something about Jesus.

So certain opponents of the film are in one sense right: Jesus sort of is Brian. In fact it is not just opponents of the film who pick up on this. This is obviously implied when Philip Davies notes the observation that "Brian both is Jesus and is clearly not Jesus" which Davies shows was a particularly useful way of allowing the film "to escape a certain amount of criticism for blasphemy or poor taste."11 From within the Python circle Terry Gilliam recalls the genesis of Brian after the completion of Monty Python and the Holy Grail (Terry Jones and Terry Gilliam, I974): "very quickly we came around to the feeling that Jesus was OK we weren't going to take the piss out of him, he was genuinely $\mathrm{OK}$, so that's where Brian got created, he was a parallel." 12 What I will now aim to show is something that has largely been overlooked in scholarly literature on Life of Brian, namely that Life of Brian furthers this overlapping by applying to Brian controversial views about Jesus (and the historical Jesus in particular) which have been put forward both in modern critical scholarship, as well as by ancient critics of what we would now call orthodox Christianity. That Monty Python created a "real" historical figure of Jesus is implied to some extent by Graham Chapman: "That movie, if it said anything at all, said think for yourselves, don't blindly follow, which I think isn't a bad message and I'm sure Mr. Christ would have agreed."13

${ }^{11}$ Davies, "Research," I 48; cf. I 50.

${ }^{12}$ Pythons, Autobiography, 353.

${ }^{13}$ Ibid., 370. 
I would also add that the following issues to be discussed in this article were very much a part of the intellectual, popular and cultural milieu at the time when Life of Brian was being written, even if we cannot pin down precisely which books were read or precise sources used for this or that theme. Indeed, not only did the Pythons read and re-read the Gospel texts and ancient literature, as several of those involved mention, ${ }^{14}$ but, as Michael Palin recalled, the Pythons immersed themselves in the world of critical gospel studies.

It was a very academic approach. We read books about the Bible story and that period, the Dead Sea Scrolls and various new interpretations of the Gospels, that sort of thing, just because we all felt, well, we can't just do silly jokes about people being knocked off donkeys, there's got to be a kind of philosophical approach as well. ${ }^{15}$

Where Davies showed how Monty Python made extensive use of ancient sources, this article will extend this approach by looking at more contemporary sources and influences, and which sort of "various new interpretations of the Gospels" influenced the writing and production of the film.

\section{Jesus and Brian: Revolutionary Comrades?}

Not unlike the disgruntled Brian, a revolutionary anti-Roman disposition has been attributed to the historical Jesus. By the time of Life of Brian, this was most famously (and then recently) argued by S. G. F. Brandon in the late I960s. ${ }^{16}$ Brandon argued that the gospel traditions were edited after the failed Jewish revolt against Rome where there was much opposition to Judaism in Christianity and, consequently, the nationalistic overtones of a revolutionary Jesus were airbrushed from history. Brandon's revolutionary Jesus never gained a widespread following in academia and quickly led to an attempted debunking by leading New Testament scholars such as Martin

${ }^{14}$ Pythons, Autobiography, 370.

${ }^{15}$ Pythons, Autobiography, 355-56, emphasis added. Davies, "Research," I 43-I 48, provides numerous parallels between Life of Brian and ancient sources, both biblical and nonbiblical.

${ }^{16}$ See e.g., S. G. F. Brandon, Jesus and the Zealots: A Study of the Political Factor in Primitive Christianity (Manchester: Manchester University Press, 1967); S. G. F. Brandon, The Trial of Jesus of Nazareth (London: B. T. Batsford, 1968). 
Hengel. ${ }^{17}$ Yet outside scholarship (even if Brandon's work was more popularising than most) the revolutionary Jesus had gained enough popular acclaim among leftist groups by the mid-twentieth century to warrant a stern rebuke from another leading New Testament scholar of the twentieth century, Günther Bornkamm.

Jesus' sayings are directed at two fronts, which are as relevant today as they were in the days of Jesus and the early Church. The first is the front of the fanatics who wish to claim Jesus for their own as the great revolutionary ... Its threat is still with us. In Marxism and Bolshevism we have today, although greatly changed, an example of its historical reality ... And these revolutionaries, when they wanted to claim Jesus as an ally in the struggle for a new world or social order, have had to learn again and again that they could not rely long on this ally ... It is therefore not surprising that today this alliance, often enough attempted in revolutionary movements of the West, has apparently been definitely renounced. ${ }^{18}$

In Life of Brian the revolutionary ambitions of Brian are absolutely explicit; or, to put it another way, the revolutionary ambitions of a very Brandonesque Jesus and a very un-Bornkamm-esque Jesus are absolutely explicit. And such a revolutionary portrait is only emphasised further through the obvious parodying of the pedantic squabbles of Marxist and leftist groups of the I970s in the portrayal of the Judean People's Front, People's Front of Judea, and so on. Brian is desperate to join the general revolutionary movement and ends up as a member of the People's Front of Judea. With the possible exception of Judith, Brian is the only sane and reasonable figure with any inkling of how to get some kind of result — no mean feat when adrift in a

${ }^{17}$ For example Oscar Cullmann, Jesus and the Revolutionaries (New York: Harper \& Row, I 970); Martin Hengel, Was Jesus a Revolutionist? (Philadelphia: Fortress, I97I). Interestingly though, the idea of an anti-imperial Jesus and anti-imperial early church has begun to reemerge in recent years and is popular at the present among New Testament scholars. See e.g., Richard A. Horsley, Jesus and the Spiral of Violence: Popular Jewish Resistance in Roman Palestine (San Francisco: Harper \& Row, 1987); John Dominic Crossan, The Historical Jesus: The Life of a Mediterranean Jewish Peasant (Edinburgh: T \& T Clark, I99I). Even conservative Christian scholars will now stress the Jesus movement as one in stark opposition to Rome. See e.g., N. T. Wright, Jesus and the Victory of God (London: SPCK, I996).

${ }^{18}$ Günther Bornkamm, Jesus of Nazareth (London: Hodder \& Stoughton, I960), Io I-2. 
sea of hopeless incompetence. Indeed, Brian's focus and anti-imperial hostilities transcend the childish revolutionary infighting during the attempt to kidnap Pilate's wife and mutilate or kill her if the demands to dismantle "the entire apparatus of the Roman Imperialist State" (27) were not met. And so when the fight breaks out between Campaign for Free Galilee and the People's Front of Judea over who thought up the kidnap idea:

BRIAN: Brothers, we should be struggling together!

FRANCIS: (between gritted teeth) We are.

BRIAN: Brothers! We mustn't fight with each other. Surely we should be united against the common enemy.

ALL: (both revolutionary groups in horrified unison) The Judean People's Front?????

BRIAN: No no, the Romans. (32)

As has been pointed out by Davies with reference to Life of Brian, revolutionary infighting was the kind of behaviour which the first-century-CE Jewish historian Josephus highlighted around the time of the failed Jewish revolt against Rome in 66-70 CE, and which according to Josephus was, if anything, more likely to cause disaster than the Romans. ${ }^{19}$ For readers who are familiar with Monty Python, the following recollection from Josephus concerning Jewish internecine fighting will almost inevitably be read as a proto-Pythonesque narrative:

The conspirators against the city being now divided into three camps, Eleazar's party, having the keeping of the sacred firstfruits, directed their drunken fury against John; the latter with his associates plundered the townsfolk and wreaked their rage upon Simon; while Simon also to meet the rival factions looked to the city for supplies. Whenever John found himself attacked on both sides, he would face his men about in opposite directions, on the one hand hurling missiles from the porticoes upon those coming up from the town, on the other repelling with his engines those who were pouring their javelins upon him from the temple.... [A]nd upon his retreat Simon advanced and did the same; as though they were purposely serving the Romans by destroying what the city had provided against a siege and severing the sinews of their own strength.... [T] he brigand chiefs, divided on all else, put to death as their common ene-

${ }^{19}$ Davies, "Research," I43-45. 
mies any in favour of peace with the Romans or suspected of an intention to desert, and were unanimous only in slaughtering those deserving of deliverance.... The rival parties ... were at grips, trampling over the dead bodies that were piled upon each other, the frenzy inhaled from the corpses at their feet increasing their savagery; and ever inventing some new instrument of mutual destruction. (Josephus, J.W. 5.I.4-5; cf. Tacitus, Histories $5.12 .4)^{20}$

We can only begin to speculate about what might have happened had someone suggested that the factions unite against the common enemy. But, unlike the tragi-comic portrayals of these revolutionary figures of both screen and (Josephus' version of) first-century history, Brian actually manages to get something done on his first revolutionary outing: the anti-Roman graffiti act. This small act of antiestablishment rebellion, like Jesus' overturning of the tables of the moneychangers and dove-sellers (Mark I I), directly leads to Brian's crucifixion.

We might make a further suggestion about one possible ramification of the idea of Brian the revolutionary and, by implication, Jesus. What Life of Brian does is show that crucifixion is far from being a unique punishment effectively reserved for Jesus (and perhaps the two bandits) in human history. Rather, Brian is just one of many people crucified at the end of the film, including people being crucified for little more than a casual punch-up. Crucifixion is referenced commonly enough in ancient sources, including, or especially, Josephus. It is perhaps worth noting that when the relatively successful bandit, Eleazar ben Dinai, was finally captured under Felix (c. 52-60 $\mathrm{CE})$ after twenty years on the run, indiscriminate crucifixions were meted out, according to Josephus: "Of the brigands whom he crucified, and of the common people who were convicted of complicity with them and punished by him, the number was incalculable" (J.W. 2.253; cf. Ant. 20.I60-6I). If the arguments presented in this article are correct, including the idea of a revolutionary Jesus underlying Brian, then could Life of Brian be further suggesting that Jesus too was little more than just another victim of indiscriminate Roman punishment in a world where people follow any old Messiah and any old prophet? ${ }^{21}$

${ }^{20}$ H. St. John Thackeray, trans., Josephus, The Loeb Classical Library 3 (Cambridge: Harvard University Press, I957), 207-I I.

${ }^{21}$ Cf. Josephus, J.W. 2.258. 


\section{Of Virgins and Resurrections}

The gospel stories of the virgin birth (Matt I-2; Luke I-2) are not the kinds of things that are going to convince the sceptic or opponent of Christianity. In fact from the second century CE (and no doubt before) opponents of Christianity have tried to explain things differently. One explanation was that the story of Mary's virginity was designed to cover up a dark secret, namely that the real father was not even the saintly Joseph but a not-sosaintly Roman soldier called Panthera. The following is the relatively famous attempted refutation by Origen (c. I $82-25$ I CE):

But let us now return to where the Jew is introduced, speaking of the mother of Jesus, and saying that "when she was pregnant she was turned out of doors by the carpenter to whom she had been betrothed, as having been guilty of adultery, and that she bore a child to a certain soldier named Panthera." And let us see whether those who have blindly concocted these fables about the adultery of the Virgin with Panthera, and her rejection by the carpenter, did not invent these stories to overturn his miraculous conception by the Holy Spirit: for they could have falsified the history in a different manner, on account of its extremely miraculous character, and not have admitted, as it were against their will, that Jesus was born of no ordinary human marriage. (Origen, Contra Celsum I.32)

Another version of this tradition occurs, for example, in the Toledoth Yeshu, a Jewish anti-Christian polemic which parodies the life of Jesus:

Near his house dwelt a widow and her lovely and chaste daughter named Miriam. Miriam was betrothed to Yohanan, of the royal house of David, a man learned in the Torah and Godfearing. At the close of a certain Sabbath, Joseph Pandera, attractive and like a warrior in appearance, having gazed lustfully upon Miriam, knocked upon the door of her room and betrayed her by pretending that he was her betrothed husband, Yohanan. Even so, she was amazed at this improper conduct and submitted only against her will. Thereafter, when Yohanan came to her, Miriam expressed astonishment at behaviour so foreign to his character. It was thus that they both came to know the crime 
of Joseph Pandera and the terrible mistake on the part of Miriam ... Miriam gave birth to a son. ${ }^{22}$

In addition to these ancient polemical traditions, countless modern day biblical critics have suggested that the gospel stories of the virgin birth are pious fictions like other stories of miraculous or unusual origins in the history of religions, such as stories in Israelite tradition (e.g., Gen I7:15-18; 2 I: I-2) or stories of major figures like Alexander the Great (Plutarch, Alexander 2.I-3.4), while scholars such as Jane Schaberg and Gerd Lüdemann have taken extremely seriously the idea that Mary was raped in their historical reconstructions of Jesus' birth. ${ }^{23}$ The development of Mariology was in many ways a pious creation of religious admirers (cf. Luke I:39-56) and a big step on the way to high Mariology, which was eventually to become associated with the Catholic Church in particular. By the I970s, this sort of reasoning had, of course, a long academic history, and would have been among the most obvious scholarly traditions for any budding sceptic to exploit. For what it is worth, we might add that, in I977, Raymond Brown published his massive and influential commentary on the infancy narratives. ${ }^{24}$ Even if the Monty Python team had not consulted this comprehensive commentary (and even if they might not have found it entirely agreeable), the ideas accepted and critiqued by Brown were at the forefront of, and "in the air" around, mainstream New Testament scholarship of the time.

Moreover, this sort of reasoning has clear echoes in Life of Brian. Brian's father, we learn from Mandy (Brian's mother), was not in fact Mr Cohen but the Roman centurion Nortius Maximus. The disbelieving Brian asks whether she was raped to which his mother replies, "Well, at first ... yes" (I 8). And to top off the not-so-subtle parallel with certain views of Jesus' origins, by the time the issue of Mandy's virginity explicitly arises in Life of Brian it is already crystal clear that she is not a virgin and that the story of her virginity gets falsely attributed to her by Brian's pious-but-stupid followers:

${ }^{22}$ Morris Goldstein, Jesus in the Jewish Tradition (New York: Macmillan, I950), I48-54.

${ }^{23}$ Jane Schaberg, The Illegitimacy of Jesus: a Feminist Theological Interpretation of the Infancy Narratives (1987; Sheffield: Sheffield Phoenix Press, 2006); Gerd Lüdemann, Virgin Birth? The Real Story of Mary and Her Son Jesus (London: SCM, 1998).

${ }^{24}$ Raymond E. Brown, The Birth of the Messiah: a Commentary on the Infancy Narratives in Matthew and Luke, revised edition (1977; London: G. Chapman, 1993). Any number of conservative, radical and liberal explanations of the virgin birth stories could be cited from the history of critical scholarship but the usual starting point, with discussions of the key positions, remains Brown's massive work of reference. 
YouTH: Excuse me.

MANDY: Yes?

YOUTH: Are you a virgin?

MANDY: I beg your pardon.

YOUTH: Well, if it's not a personal question, are you a virgin?

MANDY: "If it's not a personal question"! How much more personal can you get? Now piss off.

YOUTH: She is.

CROwD: Yeah. Definitely. (72-73)

We even get clear echoes of one of the pinnacles of Mariology, the "Hail Mary":

CROWD: Who are you?

MANDY: I'm his mother, that's who.

CROwD: Behold his mother. Behold his mother!! Hail to thee, Mother of Brian. All hail. Blessed art thou, Hosanna. All praise to thee, now and always!!! (7I; cf. John 19:27)

At the other end of the gospel story, the resurrection of Jesus is of course the big miraculous action of Christian tradition and, despite virtually all other humanities subjects having long moved on from discussing whether such spectacular miracles can or cannot happen, the debates still rage fiercely in theology and biblical studies circles. ${ }^{25}$ The sentiments of Life of Brian, it might reasonably be inferred, are on the side of those who would reject the view that Jesus was physically raised from the dead. The resurrection is implicitly challenged by providing no indication that Brian is to be resurrected from the dead, despite more-or-less following the Gospel narrative outline. In fact, Life of Brian implies the very opposite. ${ }^{26}$ Whereas the gospel

${ }^{25}$ For a recent overview of scholarship see Gary R. Habermas, "Resurrection Research from 1975 to the Present: What Are Critical Scholars Saying?" Journal for the Study of the Historical Jesus 3, no. 2 (2005): 135-53. It is only fair to point out, however, that attempts to locate conservative approaches in mainstream interdisciplinary historical research have recently been strongly emphasised. See e.g., Michael R. Licona and Jan G. Van der Watt, "The Adjudication of Miracles: Rethinking the Criteria of Historicity," Hervormde Teologiese Studies 65, no. I (2009): 62-68; Michael R. Licona, The Resurrection of Jesus: A New Historiographical Approach (Downers Grove: InterVarsity Press, 2009).

${ }^{26}$ Cf. Richard Walsh, "The Gospel according to Judas: Myth and Parable," in The Bible in Film - The Bible and Film, ed. J. Cheryl Exum (Leiden: Brill, 2006), 50. 
stories end with Jesus being resurrected from the dead, Life of Brian conspicuously ends with Brian crucified, a notable contrast given the parallel lives of the two figures. If there is escape from death-by-crucifixion in the narrative world of Life of Brian it is not supernatural but very much this worldly and merely a temporary escape from the inevitability of death. One means of escape is by sheer cunning, by falsely claiming you are the one pardoned (96-97). Another is to have a rescue party arranged, perhaps led by your brother (95). Yet another is to have some do-gooder take your place (89-90, 94; cf. Mark I 5:2 I). But while there are some relatively old traditions which have Jesus somehow avoiding crucifixion (cf. Gospel of Barnabas 217-18; Qur'ān 4: I 57-58) as Philip Davies notes in relation to Life of Brian, ${ }^{27}$ Brian is clearly not so fortunate, emphasised by a sorry string of misunderstanding and incompetence, from the rendition of "For He's a Jolly Good Fellow" to the crack suicide squad (compare Masada ${ }^{28}$ ) pointlessly killing themselves even after the guards have fled in terror. Brian's stark fate is finally and conclusively underscored by Eric Idle's famous song, "Always Look on the Bright Side of Life," where a full embrace of the joys of this life is the only challenge to the inevitability of an eternity in the dust:

Always look on the right side of life ...

For life is quite absurd

And death's the final word

Enjoy it—it's your last chance anyhow.

So always look on the bright side of death

Just before you draw your terminal breath

Life's a piece of shit

When you look at it

Life's a laugh and death's a joke, it's true

I mean what have you got to lose? You know you come from nothing, you're going back to nothing. What have you lost? Nothing! Nothing will come from nothing ... Cheer up. Give us a grin! (IOO-IOI)

${ }^{27}$ A point noted in Davies, "Research," I 47.

${ }^{28}$ Davies, "Research," I 44, further suggests a superficial parody of Japanese suicide squads. 


\section{He's not the Messiah}

Some biblical scholars believe that Brian was not the only one who did not claim to be the Messiah while others went ahead and made a dubious link. Given the absence of the term on the lips of Jesus in Matthew, Mark and Luke, it is often argued that Jesus never regarded himself as "the Messiah," at least in the titular sense, and that the title was developed by the gospels or earlier post-Jesus tradition. There has of course been a major scholarly theory developed to explain the transition from Jesus not thinking he was "the Messiah" to the first Christians believing he was, namely the "Messianic secret" theory provided by William Wrede in I90 I in relation to the earliest of the gospels, Mark..$^{29}$ Despite criticisms and qualifications it remains a very popular theory to this day. It is one of the most basic theories taught in critical biblical studies and was, significantly enough, translated into English in I97 I. ${ }^{30}$ Put crudely, it was and is argued that the Messianic secrecy theme was a theological device developed by the writer of Mark's Gospel to explain the problem of why the historical Jesus was not believed to be, or did not claim to be, the Messiah. The writer of Mark's Gospel, so dominant forms of the argument go, made sure to construct a Jesus who kept his true identity quiet and did not want it revealing until after the resurrection. In other words, the messianic identity of Jesus was effectively a creation of Jesus' followers and not from the historical Jesus himself. The Messianic secrecy theme was and is built on the peculiar emphasis in Mark's gospel where Jesus commands demons to be silent because they know who he really is (Mark I:25, $34 ; 3:$ I I-I 2 ), tells cured individuals to be quiet about what has happened (Mark I:44; 5:43; 7:36; 8:26), and even asks his disciples not to tell anyone grand claims (Mark 8:30; 9:9). The disciples are frequently taught in private and frequently misunderstand him. To add to the confusion the Markan Jesus suggests to his disciples that his parables were designed to confuse:

And he said to them, "To you has been given the secret (or: mystery) of the kingdom of God, but for those outside, everything

${ }^{29}$ William Wrede, Das Messiasgeheimnis in den Evangelien (Göttingen: Vandenhoeck \& Ruprecht, I90I).

${ }^{30}$ J. C. G. Greig, The Messianic Secret (Cambridge: James Clarke, I97I). See further e.g., James L. Blevins, The Messianic Secret in Markan Research I90I-1976 (Washington: University Press of America, I98I); C. M. Tuckett, ed., The Messianic Secret (London: SPCK, I983); Heikki Räisänen, The "Messianic Secret" in Mark's Gospel (Edinburgh: T \& T Clark, I990); W. R. Telford, The Theology of the Gospel of Mark (Cambridge: Cambridge University Press, I999), 4I-54. 
comes in parables; in order that 'they may indeed look but not perceive, and may listen, but not understand; so that they may not turn again and be forgiven.'” (Mark 4: IO-I2)

Something roughly akin to the scholarly secrecy theory can easily be noted in a critical reading of the Gospel texts, at least in the sense that the first Christians were in the process of conveniently remembering great things about Jesus or neglecting to tell people certain dramatic events (cf. Mark I6:8). Look at the following gospel texts and note the role of interpretation by followers (a key theme in Life of Brian, of course):

The Jews said to him, "What sign can you show us for doing this?" Jesus answered them, "Destroy this temple, and in three days I will raise it up." The Jews then said, "This temple has been under construction for forty-six years, and will you raise it up in three days?" But he was speaking of the temple of his body. After he was raised from the dead, his disciples remembered that he had said this; and they believed the scriptures and the word that Jesus had spoken. (John 2:19-22)

As they were coming down the mountain, he [Jesus] ordered them [certain disciples] to tell no one about what they had seen [the transfiguration], until after the Son of Man had risen from the dead. So they kept the matter to themselves, questioning what this rising from the dead might mean. (Mark 9:9-10)

Rightly or wrongly, a hermeneutic of suspicion, coupled with a non-Christian perspective, might almost inevitably lead to slightly sarcastic mutterings that someone else might be making some remarkable claims on behalf of Jesus here and without his consent. Such a combination of scepticism and suspicion is clear in John Cleese's assessment of the gospel miracles which, incidentally, is close to Geza Vermes' discussion of Jesus as a charismatic healer and exorcist ${ }^{31}$ from a book which seems to have directly or indirectly influenced Life of Brian (see below), and a view which has a long scholarly pedigree:

${ }^{31}$ Geza Vermes, Jesus the Jew: A Historian's Reading of the Gospels (London: SCM, I973), 22-23: "Four of them [exorcism stories] ... describe as demonic possession what seems to have been mental or nervous illness ... It ought to be mentioned at this juncture that the psychiatrist whom I have consulted on the question whether most of the diseases exorcised or healed in the New Testament could be recognized as hysterical, after giving a qualified affirmative reply, wished to know the success rate of the treatment and the state of health of the patients six months after discharge!" By the I970s, the most prominent book on miracles 
I don't know about the miracles, I mean a lot of the healing, the faith healing, I would imagine was absolutely sensible. I mean anyone who is suffering from the symptoms of something that's basically got a hysterical foundation then that could easily happen. I would have thought that just as much as faith healing is a fact of life. It all makes sense to me. Water into wine I would be very dubious about, frankly Brian [laugh]. Over the moon if it happened but ... ${ }^{32}$

We might also note that where the I970s opened with the English translation of Wrede, it wound down with another prominent book on mystery in the Gospels, Frank Kermode's The Genesis of Secrecy, initially delivered as the Charles Eliot Norton Lectures at Harvard between 1977 and 1978 and including an opening chapter on that classic problem of the riddle of Markan parable telling (Mark 4:II-I2). ${ }^{33}$ Whilst not positing direct sources, it is clear that ideas concerning secrecy, linked in with Jesus' identity, were very much part of creative mainstream New Testament scholarship as Life of Brian was coming into being. ${ }^{34}$ Life of Brian clearly has some very real parallels to followers making claims about their figurehead without permission and going well beyond what was actually said. Miracles wrongly and stupidly get attributed to him and the crowd wrongly believe signs have been presented. And all along, of course, Brian wants nothing to do with the idea that he is the Messiah or indeed anything special.

BRIAN: I am not the Messiah, will you please listen! I am not the Messiah. D'you understand. Honestly!

GIRL: Only the true Messiah denies his divinity.

BRIAN: What!? Oh! (in exasperation) What sort of a chance does that give me? ... All right! I am the Messiah! Uproar.

CROwd: He is! He is the Messiah!

They all fall on the ground and worship him.

BRIAN: Now fuck off!!! (64-65)

in the Gospel tradition, Hendrik van der Loos, The Miracles of Jesus (Leiden: Brill, 1965), was also entertaining similar ideas.

32 The Pythons: Somewhere in Tunisia, Circa A.D. 1979, 50 min (BBC, 1979).

${ }^{33}$ Frank Kermode, The Genesis of Secrecy: On the Interpretation of Narrative (Cambridge: Harvard University Press, 1979).

${ }^{34}$ I owe this latter point on Kermode to Deane Galbraith. 
Note too the state Brian had just previously left the crowd by neglecting to finish off his parables once the Romans were out of sight, the very point where the crowd shake off their disdain and start getting interested. Paradoxically, it is Brian the hopeless storyteller who, without thinking, leaves his story tantalisingly unfinished and with his audience wanting more, the one narrative device which any storyteller worth their salt might use. Now Brian has got the confused crowd hooked and wanting the explanations of his mysteries and secrets yet ultimately they remain confused.

Youth: Why won't he tell us?

ELSIE: I don't know.

YOUTH: Is it a secret?

BRIAN: No ...

YOUTH: Is it?

ELSIE: It must be. Otherwise he'd tell us.

ARTHUR: (to Brian) What is the secret?

BRIAN: Leave me alone.

OTHERS: Yes! Tell us the secret!

YouTH: What is the secret?

GIRL: Is it the secret of Eternal Life? ${ }^{35}$

ELSIE: He won't say.

ARTHUR: Of course not-if I knew the secret of Eternal Life, I wouldn't say. (56-57)

It is worth adding that in the gospels it is precisely after Jesus has given the Parable of the Sower (Mark 4:I-8), and precisely before he gives the explanation to the parable (Mark 4:I 3-2O), that we get the above mentioned discussion of mysteries, explanations and outsiders (Mark 4:IO-I2).

\section{Good Jewish Boys}

Another point of historical Jesus research which influenced Life of Brian is the seemingly banal fact that Jesus was a Jew. In modern historical Jesus scholarship the phrase "Jesus the Jew" is a well known scholarly cliché but in the early I970s it was anything but a banal fact. In 1973 Geza Vermes published one of the most famous books in historical Jesus studies with the then

${ }^{35}$ Compare e.g., John 5:39-42; 17:3; 20:30-3 I. 
revolutionary title, Jesus the Jew. Some reviewers—but far from all-were suitably outraged at this suggestion, although some of the criticisms appear to follow the route of being more indirectly critical of the theory and more critical of the abilities of the scholar. As Vermes recalls in his autobiography,

A Jewish critic, violently resenting my refusal to classify Jesus as a Pharisee, put me among the anti-Semites. A well known English Jesuit now deceased described the book's learning as "at times ... oppressive." He blamed the "overcrowded" character of the volume on my "apparent desire" to show off my familiarity with Christian biblical criticism! An American Bible expert, taking exception to my light-hearted remark that New Testament scholars often wear the blinkers of their trade, haughtily dismissed the book with "Jesus the Jew deserves better than this." A French woman writer, contributing to a right-wing magazine, settled for the double denunciation of "scandal and blasphemy." 36

Famously, Vermes' Jesus is not the Christ of conventional Christian faith. He was a charismatic holy man of Jewish tradition who observed the biblical commandments such as Sabbath and food laws and happened to be crucified through being in the wrong place at the wrong time. He did not think of himself as the Messiah or anything too grand. In fact most of the titles the historical Jesus might have used (e.g., son of man, son of God, etc.) are shown by Vermes to have a more this-worldly frame of reference as opposed to indicating anything like the second person of the Trinity. Despite the consistent scholarly rhetoric that Jesus was a Jew, this emphasis has caused some problems for Christian academics. There are endless scholarly constructions of Jewish identity as effectively fixed and stable which has a key function of providing "the Jewish background" to be transcended by Jesus (who rhetorically remains "very Jewish" in doing so), no doubt in part because of a socio-religious pressure to show to the faithful that he was still something a bit more spectacular than just a charismatic holy man. ${ }^{37}$

${ }^{36}$ Geza Vermes, Providential Accidents: An Autobiography (London: SCM, I 998), 2 I 3-I 4.

${ }^{37}$ For discussion see especially William E. Arnal, The Symbolic Jesus: Historical Scholarship, Judaism and the Construction of Contemporary Identity (London: Equinox, 2005); James G. Crossley, Jesus in an Age of Terror: Scholarly Projects for a New American Century (London: Equinox, 2008), I 43-94. 
It is important to put this scholarly and cultural tradition in a wider historical and cultural perspective. Prior to Vermes the dominant position in critical scholarship (and more broadly in popular understandings of Jesus) —influenced by nearly two thousand years of church teaching — was to sharply differentiate Jesus from Judaism. In the context of Nazi Germany this reached new depths with some now truly bizarre-sounding claims, such as Walter Grundmann's argument that Jesus was more likely to have been of Aryan descent. ${ }^{38}$ Grundmann belonged to the Nazi party and was a supporting member of the SS yet, despite the obvious antisemitic influences on his work, continued to be regarded as a serious scholar well beyond I945. Grundmann was far from the only Nazi involved in New Testament scholarship. ${ }^{39}$ Even though Nazi Christians were discredited after the Second World War, anti-Judaism was a constant feature of post-war New Testament scholarship. But, despite the discrediting of Nazi Christian scholars, the lack of interest in the "Jewishness" of Jesus, the clear differentiation of Jewish Christians like Paul from Judaism, and the generally negative construction of early Judaism, remained firmly rooted in New Testament scholarship and the churches, even among those who were opponents of antisemitism and the Nazi party. ${ }^{40}$ Buoyed along by a sea change in dominant Anglo-American attitudes towards Israel, the Holocaust and Judaism after the Six Day War, ${ }^{41}$ Vermes' Jesus the Jew in turn paved the way for the positive receptions of E. P.

${ }^{38}$ For further discussion see e.g., Susannah Heschel, "Nazifying Christian Theology: Walter Grundmann and the Institute for the Study and Eradication of Jewish Influence on German Church Life," Church History 63, no. 4 (1994): 587-605; Maurice Casey, "Some AntiSemitic Assumptions in The Theological Dictionary of the New Testament," NovT 4I, no. 3 (1 999): 280-9I; Peter M. Head, "The Nazi Quest for an Aryan Jesus," Journal for the Study of the Historical Jesus 2, no. I (2004): 55-89; Susannah Heschel, The Aryan Jesus: Christian Theologians and the Bible in Nazi Germany (Princeton: Princeton University Press, 2010).

${ }^{39}$ Gerhard Kittel, for instance, was not only a Nazi propagandist but also editor of the Theological Dictionary of the New Testament (Gerhard Kittel and Gerhard Friedrich, eds., Theologisches Worterbuch zum Neuen Testament, Io vols. (Stuttgart: Kohlhammer, 1933-79)). This work is still recommended to undergraduates and still utilised by leading professors despite many of the early contributions being riddled with and distorted by antisemitism and antiJudaism. Grundmann also participated in the TWNT project. For further discussion see e.g., Casey, "Anti-Semitic Assumptions."

${ }^{40}$ See further e.g., Daniel Boyarin, A Radical Jew: Paul and the Politics of Identity (Berkeley: University of California Press, I994), 2 I 2-I4; Casey, "Anti-Semitic Assumptions"; Shawn Kelley, Racializing Jesus: Race, Ideology and the Formation of Modern Biblical Scholarship (London: Routledge, 2002); James G. Crossley, Why Christianity Happened: A Socio-Historical Account of Christian Origins, 26-50 CE (Louisville: Westminster John Knox, 2006), chapter I.

${ }^{41}$ Crossley, Jesus in an Age of Terror, 177-94. 
Sanders' Paul and Palestinian Judaism, which perhaps more than any work in New Testament studies made scholars aware of the extent to which Judaism was cast in a negative light. ${ }^{42}$ Without this context it is easy to underestimate the then unusual nature of Vermes' portrait of Jesus the Jew, even if it was starting to become partly domesticated (at least in scholarship) by the I 980 os. Yet one other context might illuminate the once surprising nature of this view with further relevance for Life of Brian: just think of the clichéd cinematic and visual images of the blond-haired, blue-eyed Christ. Vermes' major point that Jesus was a Jew and was very different from the Christ of faith has distinct echoes in Life of Brian, released only five years after the publication of Jesus the Jew. Brian is, of course, anything but the Christ of faith and is a fairly "ordinary" Jew who wears a skull cap as a matter of routine. Despite his spectacularly un-Semitic forename ("Christian name" would certainly be the wrong term here) ${ }^{43}$ his surname, "Cohen," is as recognisably Jewish as could be imagined. Indeed, one of Brian's particular concerns in the face of Roman occupation is his Jewish identity and he only attempts to use his Roman connections to escape crucifixion (40). When stunned about the news of his father being a Roman, Brian throws an adolescent tantrum, proclaiming (19), "I'm not a Roman, Mum, and never will be! I'm a Kike! A Yid! A Hebe! A Hook-nose! I'm Kosher, Mum. I'm a Red Sea Pedestrian and proud of it!" 44

\section{Fell in Love with a Girl?}

One final point that is also well worth noting has to do with sexual love, a question which almost inevitably gets raised in the secularised or less pious quarters of theological reflection on the humanity of Jesus. The canonical gospels and Christian orthodoxy do not explicitly entertain the idea that Jesus had sexual feelings for another human being. But the view that Jesus was in love in some way or other with Mary Magdalene has been a subversive view of Jesus which dates back to the first few centuries after Jesus' death and has recently proven popular, if the success of the Da Vinci Code and a

${ }^{42}$ E. P. Sanders, Paul and Palestinian Judaism: A Comparison of Patterns of Religion (Philadelphia: Fortress, 1977).

43 Davies, "Research," I 50.

${ }^{44}$ See also Adele Reinhartz, "Jesus in Film: Hollywood Perspectives on the Jewishness of Jesus," The Journal of Religion and Film 2, no. 2 (I998), http://www. unomaha.edu/ -jrf/JesusinFilmRein.htm. 
whole host of sensationalist "non-fictional" books are anything to go by. This tradition also has a major cinematic moment, of course, in The Last Temptation of Christ (Martin Scorsese, I 988), based on the 1950s novel by Nikos Kazantzakis, ${ }^{45}$ which was released less than ten years after Life of Brian. The key ancient text for the tradition of Jesus' relationship with Mary Magdalene, even if it has or has not been misread, is the apocryphal Gospel of Philip. Here Mary was Jesus' consort, favoured among the disciples and the woman who Jesus used to kiss on the mouth (Gospel of Philip Saying 59; cf. Saying 36). To spell out the obvious, Brian too has a romantic fling with his fellow revolutionary Judith and it is undeniably clear that they engaged in an enjoyable night which moved well beyond heavy petting. This is clearer still in the script:

BRIAN stirs in bed, and opens his eyes, to see the naked form of JUDITH beside him. Clearly certain unspecified but apparently rude behaviour has taken place during the night. BRIAN smiles warmly at the memory ... (66)

JUDITH: Brian, you were fantastic!

BRIAN: Well, you weren't so bad yourself.

JUDITH: No no ... What you said just now was quite extraordinary. (77)

\section{Conclusion}

Legal considerations aside, whether we call all of this blasphemous and/or offensive is in the eye of the blasphemed and/or offended. Many-though certainly not all —of the ideas surrounding the historical Jesus and applied to Brian in the film have been accepted by the more critically minded members of the various Christian churches. As Carl Dyke points out, but in a different way via Gramsci and the usual Christ-Brian distinction, Life of Brian may not be as counter-hegemonic as some, like Dyke's younger self, might like to think. ${ }^{46}$ But there is no end to the Christians who are at least uncomfortable with critical readings of biblical texts, occasionally with faint echoes

\footnotetext{
${ }^{45}$ Nikos Kazantzakis, The Last Temptation of Christ, trans. Peter A. Bien (I955; New York: Simon \& Schuster, 1960).

${ }^{46}$ Dyke, "Learning from The Life of Brian," 240-4I, 248-50. See also Walsh, "Gospel according to Judas," 49-50.
} 
of medieval heresy allegations. ${ }^{47}$ From such a perspective Life of Brian is not so sweet and innocent. It subtly but clearly takes up some of the more challenging reconstructions of the historical Jesus from popular and scholarly thought and applies them to Brian. The physical Jesus in the film may be the Christ of faith who is never directly challenged but this Christ of faith is undermined by the portrayal of Brian who is, in effect, the historical Jesus of more mildly subversive imaginations.

${ }^{47}$ Hence even N.T. Wright, a scripturally ultra-conservative Christian scholar and former bishop of Durham (UK), has come in for some furious criticisms from the Reformed pastor Dr C. Matthew McMahon and in language which would grace a Monty Python sketch and even Life of Brian itself. Wright is denounced as a "heretic. A heresiarch. He will forever burn under God's righteous wrath and under the solemn and scornful gaze of the Lamb of God for all eternity if he does not change his theological views before he dies, or rather, his lack of good theology! He is a false teacher, and one of the most influential heretics of the century because he affected people at the seminary level—where pastors are trained and scholars born-and has infected a good number of churches, right down to the layman and youth of the day ... Wright, as I said, a HERETIC ... This is Romanism repackaged ... you are being plagued by this man who is taking down many young in the faith to hell with him by his heretical views which basically gut the Gospel of any power, spit on Christ's work, and destroy the orthodox doctrine of justification as it has been taught throughout the history of the church." This is from McMahon's website, http://www.puritanboard.com and the above quotation is from, http://www.puritanboard.com/forum/viewthread.php?tid=I 56 I 2 \&page= I. The connection between McMahon's views and Monty Python's famous Spanish Inquisition sketch has also been made on Chris Tilling's blog: http://www.christilling.de/brainpoo/2005/I 2/nobodyexpects-spanish-inquisition.html. 